\title{
Effect of Different Dates and Irrigation Regimes on Growth, Yield and Consumptive Use of Some Wheat Varieties Under Sohag Governorate Conditions
}

\author{
Gameh, M.A. ${ }^{\text {; E.M. Ahmed }}{ }^{1}$; K.A. Mohamed ${ }^{2}$ and M.A.M. Ahmed ${ }^{2}$ \\ ${ }^{1}$ Department of Soil and Water, Faculty of Agriculture, Assiut University \\ ${ }^{2}$ Soil, Water and Environment Research Institute, (ARC)
}

Received on: $15 / 11 / 2016$

Accepted for publication on: 12/12/2016

\section{Abstract}

Field experiments were conducted at Shandaweel Agricultural Research Station, during the three winter successive seasons (2012/2013, 2013/2014 and $2014 / 2015)$ to find out the effect of different dates and irrigation regimes on growth, yield and consumptive use of three wheat varieties under Sohag governorate conditions. Three bread wheat cultivars (Shandaweel-1, Giza-168 and Sids-12) were cultivated in two different sowing dates $\left(20^{\text {th }}\right.$ November and $5^{\mathrm{h}}$ December) under three irrigation intervals treatments of 21, 28 and 35 days. The experiment was laid out in a split - split plot design with three replications.

The results revealed significant differences among studied cultivars and irrigation treatments in most studied traits in all seasons. The second sowing date $5^{\text {th }}$ December produced the best results of the growth components, grain yield and water use efficiency through the years of this study. The irrigation at 21 days gave the best values of grain yield values (18.234, 16.609 and $17.198 \mathrm{ardab} / \mathrm{fed})$ for the three winter seasons 2012/13,2013/14 and 2014/15. The average water consumptive use by wheat plants were 2094.48 for $\mathrm{I}_{1}, 1883.46$ for $\mathrm{I}_{2}$ and 1564.15 for $\mathrm{I}_{3} \mathrm{~m}^{3} /$ fed. at the first sowing date $\left(20^{\text {th }}\right.$ Nov.) while it was 2123.93 for $\mathrm{I}_{1}$, 1811.49 for $\mathrm{I}_{2}$, and 1606.19 for $\mathrm{I}_{3} \mathrm{~m}^{3} /$ fed for the second sowing date $\left(5^{\text {th }}\right.$ Dec.). The irrigation water use efficiency was higher with using the irrigation treatment every 35 days. It was $0.53,0.54$, and $0.61 \mathrm{kgm}^{-3}$ for the first sowing date $\left(20^{\text {th }}\right.$ November) and it was $0.64,0.68$, and $0.68 \mathrm{kgm}^{-3}$ for the second sowing date $\left(5^{\text {th }}\right.$ December) by using the irrigation interval treatment at 21,28 , and 35 days, respectively.

Shandaweel 1 produced the highest values of grain yield and water use efficiency at the two sowing dates and the irrigation regimes. Also the results of the second sowing date $\left(5^{\text {th }}\right.$ December) for Shandaweel 1 were higher than these of first sowing date.

Keywords: Wheat, Irrigation regimes, Irrigation dates.

\section{Introduction}

Oriented agricultural research is mostly directed to alleviate the problem of food shortage with our limited water resources.

Wheat triticum asetivum is the main food crop in Egypt. As in the most of world there is a gap between production and consumption. In Egypt, wheat is commonly known as the king of cereal crops used as a major food crop. Its cultivated area reached about 2.9 million feddan (fed $=0.42$ hectare) with an average production of 18.1 ardab per feddan of grains $(\operatorname{ardab}=150 \mathrm{~kg})(\mathrm{FAO} 2008)$. 
However, this local production doesn't meet the consumption owing to the increased population with a limited cultivated area and water resources (El-Shaer et al. 1997 and Eid et al. 1999).

Khater et al., (1997) found that, spikes $/ \mathrm{m}^{3}, 1000$ grain weight, straw and grain yield/fed were significantly decreased with decreasing available soil moisture content.

EL Kalla et al., (1994) found the same result and add the plant height. Rayan et al., (1999) indicated that seasonal wheat water consumptive use at Shandaweel region (Upper Egypt) was veiled between 1883 and $1930 \mathrm{~m}^{3} / \mathrm{fed}$.

Khalil. et al., (2006) found that the irrigation treatment at 1.2 evaporation pan coefficient recorded the highest amount of water consumed .more than the other two treatment water consumptive uses by wheat were $1582 \mathrm{~m}^{3} /$ fed $1796.9 \mathrm{~m}^{3} /$ fed and $2215.9 \mathrm{~m}^{3} /$ fed for irrigation treatment at $0.8,1,1.2$ evaporation pan coefficient. The irrigation at 0.8 evaporation pan coefficient gave the highest value of water use efficiency.

With respect to crop productivity as a function for the soil moisture availability during the growing season, Mohamed and Tammam (1999), Sidrak (2003) and Moussa and Abdel-Maksoud (2004) reported that the number of spikess $/ \mathrm{m}^{2}, 1000$-grain weight, straw and grain yields decreased due to the irrigation at the high soil moisture depletion.

El-Marsafawy (2000) and Rayan et al. (2000) found that the highest values of grain yield were obtained when wheat crop irrigated at
1.0 evaporation pan coefficient (EPC) compared with 1.4.

El-Sabbagh et al, (2002) in Egypt and Metin-Sezen and AttilaYazar (2006) in the arid Southeast Anatolia of Turkey, recorded that short irrigation intervals $(7,14$ and 21 days) increased the plant height, spikes length, number of spikess $/ \mathrm{m}^{2}$, number and weight of grain/spikes, 1000- grain weight, harvest index and straw and grain yields compared with prolonged irrigation intervals (35 days).

The main objective of this study is to determine the best irrigation regimes by using different irrigation intervals under two different sowing dates for wheat production.

\section{Materials and Methods}

A field experiment was carried out at Shandaweel Agricultural Research Station, ARC, Egypt, during the winter of 2012/2013, 2013/2014, and 2014/2015 growth seasons to study the effect of different dates and irrigation regimes on growth, yield and consumptive use for three wheat varieties under Sohag governorate conditions. The experiment was laid out in a split - split plot design with three replications. The plot area was $42.0 \mathrm{~m}^{2}(6 \times 7 \mathrm{~m})$.

The main plots were devoted to sowing dates of $\mathrm{S} 1=$ first sowing date $\left(20^{\text {th }} \quad\right.$ November $) \mathrm{S} 2=$ second sowing date $\left(5^{\text {th }}\right.$ December); the sub plots were assigned to the irrigation regime as intervals of $\mathrm{I} 1=21$ days, $\mathrm{I} 2=28$ days, and $\mathrm{I} 3=35$ days, and the sub_ sub plots were assigned to three wheat cultivars including V1 = Shandaweel 1, V2 = Giza 168 and V3 = Sides 12. 
Wheat seeds of the three cultivars were broadcasted at a rate of 60 $\mathrm{kg} /$ fed $(144 \mathrm{~kg} \mathrm{/} \mathrm{ha),} \mathrm{the} \mathrm{recom-}$ mended levels of basic fertilizers (NPK) were applied. All experimental plots were fertilized using nitrogen fertilizer, that was applied in the form of urea $(46.5 \% \mathrm{~N})$, super phosphate $\left(15 \% \mathrm{P}_{2} \mathrm{O}_{5}\right)$, and potassium sulphate $\left(48 \% \mathrm{~K}_{2} \mathrm{O}\right)$, at the level of $70 \mathrm{~kg} \mathrm{~N}$ /fed, $15 \mathrm{~kg} \mathrm{P}_{2} \mathrm{O}_{5} / \mathrm{fed}$, and $24 \mathrm{~kg}$ $\mathrm{K}_{2} \mathrm{O} /$ fed, respectivly.

The nitrogen and potassium fertilizers were divided and added into equal doses, the first one with the first irrigation and the second was added with the second irrigation However, the phosphate fertilizer was added before planting.

Meteorological data used in calculating the potential water consumptive use were collected from Sohag 623970 station (latitude of $26^{\circ}: 6$, longitude of $37^{\circ}: 7$ and elevation of $70 \mathrm{~m}$ ) during the growth seasons (Table 1).

Table 1. The meteorological data at Sohag 623970 Station during 2012/2013, 2013/ 2014 and $2014 / 2015$ seasons.

\begin{tabular}{|c|c|c|c|c|c|c|c|c|}
\hline \multirow{2}{*}{$\begin{array}{l}\text { Season } \\
\text { Month }\end{array}$} & \multicolumn{8}{|c|}{ 2012/2013 season } \\
\hline & $T \max \left(C^{0}\right)$ & $T \min \left(C^{0}\right)$ & $\begin{array}{c}\text { WS } \\
2 \mathrm{~m}(\mathrm{~km} / \\
\text { day })\end{array}$ & $\begin{array}{l}\text { RH } \\
(\%)\end{array}$ & $\begin{array}{c}\text { RF } \\
(\mathbf{m m})\end{array}$ & $\begin{array}{c}\text { SS } \\
\text { (hours) }\end{array}$ & $\begin{array}{c}\text { SR } \\
\left(\mathrm{MJ} / \mathrm{m}^{2} / \mathrm{day}\right)\end{array}$ & $\begin{array}{c}\mathbf{E ~ p} \\
(\mathbf{m m})\end{array}$ \\
\hline Nov. & 28.1 & 6.7 & 113.7 & 54.8 & 0.0 & 9.3 & 16.5 & 3.20 \\
\hline Dec. & 21.4 & 7.6 & 159.9 & 65.0 & 0.0 & 9.0 & 14.9 & 2.73 \\
\hline Jan. & 21.3 & 12.1 & 123.8 & 60.0 & 1.0 & 9.0 & 15.7 & 2.53 \\
\hline Feb. & 24.0 & 14.0 & 164.2 & 48.0 & 0.0 & 9.8 & 18.9 & 3.75 \\
\hline Mar. & 29.7 & 20.1 & 169.9 & 35.0 & 0.0 & 9.8 & 21.7 & 5.23 \\
\hline Apr. & 29.9 & 13.0 & 168.5 & 34.0 & 0.0 & 10.1 & 24.3 & 5.94 \\
\hline May & 37.8 & 17.6 & 159.9 & 30.0 & 0.0 & 11.3 & 26.9 & 7.17 \\
\hline Mean & 27.5 & 11.6 & 151.4 & 46.7 & Total1.0 & 9.8 & & 4.43 \\
\hline \multicolumn{9}{|c|}{ 2013/2014 season } \\
\hline Nov, & 28.4 & 13.2 & 132.5 & 59.0 & 0.0 & 9.3 & 16.5 & 3.32 \\
\hline Dec. & 21.6 & 7.6 & 216.0 & 58.0 & 0.0 & 9.0 & 14.9 & 3.07 \\
\hline Jan. & 22.5 & 6.3 & 152.6 & 58.0 & 0.0 & 8.9 & 15.6 & 2.91 \\
\hline Feb. & 23.8 & 7.6 & 216.0 & 52.0 & 0.0 & 9.8 & 18.9 & 4.11 \\
\hline Mar. & 27.4 & 12.3 & 210.2 & 45.0 & 9.2 & 9.8 & 21.7 & 5.25 \\
\hline Apr. & 32.8 & 15.8 & 190.1 & 37.0 & 0.0 & 10.1 & 24.3 & 6.58 \\
\hline May & 34.7 & 19.8 & 172.8 & 36.0 & 0.4 & 11.3 & 26.9 & 7.17 \\
\hline Mean & 27.3 & 11.8 & 184.3 & 49.3 & Total 9.6 & 9.7 & & 4.63 \\
\hline \multicolumn{9}{|c|}{ 2014/2015season } \\
\hline Nov. & 26.4 & 11.9 & 95.0 & 43.0 & 1.5 & 9.3 & 16.5 & 3.01 \\
\hline Dec. & 22.8 & 8.5 & 103.7 & 48.0 & 0.7 & 9.0 & 14.9 & 2.51 \\
\hline Jan. & 19.5 & 5.5 & 95.0 & 43.0 & 0.6 & 8.9 & 15.6 & 2.40 \\
\hline Feb. & 22.8 & 8.1 & 112.3 & 33.0 & 0.4 & 9.8 & 18.9 & 3.42 \\
\hline Mar. & 27.7 & 12.3 & 129.6 & 29.0 & 0.7 & 98 & 21.7 & 4.76 \\
\hline Apr. & 30.1 & 13.0 & 146.9 & 21.0 & 0.5 & 10.1 & 24.3 & 5.89 \\
\hline May & 35.8 & 19.4 & 146.9 & 17.0 & 0.0 & 11.3 & 26.9 & 7.09 \\
\hline Mean & 26.4 & 11.2 & 118.5 & 33.4 & Total4.4 & 9.7 & & 4.15 \\
\hline
\end{tabular}

Some soil physical and chemical properties were measured as (Table 2) follow: Particle size distribution according to Gee and Bauder (1986). 
Table 2. Some physical and chemical properties of the soil.

\begin{tabular}{|lc|}
\hline \multicolumn{1}{|c|}{ Particle-size distribution Soil fraction } & Content (\%) \\
\hline \hline Coarse sand & 7.80 \\
Fine sand & 16.20 \\
Silt & 38.20 \\
Clay & 37.80 \\
Textural class & Clay loam \\
\hline Soil chemical analyses & \multicolumn{1}{c|}{ Content } \\
\hline \hline Organic matter & $1.22 \%$ \\
Available N (K Cl-extract) & $17.20 \mathrm{mg} \mathrm{kg}^{-1}$ \\
Available P (Na HCO3 extract) & $10.00 \mathrm{mg} \mathrm{kg}^{-1}$ \\
Available K (N H4 - a acetate extract) & $178 \mathrm{mg} \mathrm{kg}^{-1}$ \\
pH (1:2.5, soil: water suspension) & 7.9 \\
ECe & $0.9 \mathrm{dSm}^{-1}$ \\
\hline
\end{tabular}

Available $\mathrm{N}$ was determined according to Bremner and Mulvaney (1982). Available P was determined according to Olsen et al., (1954). Available K was determined according to Hesse, (1972). The EC was estimated according to Richards (1954) and soil $\mathrm{pH}$ was determined according to McLean (1982).
Field capacity and wilting point were determined according to Cassel and Nielsen (1986). Available water was calculated from the difference between field capacity and wilting point. Bulk density was determined according to Blake and Hartge (1986), (Table3).

Table 3. Soil moisture constants (\% by weight) and bulk density ( $\mathrm{mg} \mathrm{m}^{-3}$ ) of the soil site at Shandaweel Agricultural Research Station.

\begin{tabular}{|c|c|c|c|c|}
\hline $\begin{array}{l}\text { Depth } \\
\text { (cm) }\end{array}$ & $\begin{array}{c}\text { Field capacity } \\
\text { (\%) }\end{array}$ & $\begin{array}{c}\text { Wilting point } \\
(\%)\end{array}$ & $\begin{array}{c}\text { Available water } \\
(\%)\end{array}$ & $\begin{array}{c}\text { Bulk density } \\
\left(\mathrm{Mg} \mathrm{m}^{-3}\right)\end{array}$ \\
\hline $00-15$ & 32.20 & 13.77 & 18.43 & 1.15 \\
\hline $15-30$ & 31.78 & 13.18 & 18.60 & 1.20 \\
\hline $30-45$ & 29.73 & 12.40 & 17.33 & 1.22 \\
\hline $45-60$ & 29.19 & 11.18 & 17.39 & 1.28 \\
\hline
\end{tabular}

The field capacity, wilting point and available soil moisture of the experimental field were determined and were $30.69 \%, 12.63 \%$, and $18.06 \%$ respectively. The soil was clay loam in texture with bulk density of 1.22 $\mathrm{Mg} \mathrm{m}^{-3}$ (Tab12\&3). Soil samples were taken from each $15 \mathrm{~cm}$ depth up to 60 $\mathrm{cm}$ from the surface.

Growth, Yield and some Yield Attributes Esteimation
At harvest, the plants of each entire sub- sub -plot were sampled in order to determine some wheat parameters such as:

1. Total yield (ton/fed).

2. Grain yield (keg /fed.).

3. Straw yield (ton/fed). weight).

4. Seeds index (1000 grain

5. 5 spike grain weight (gm).

All obtained data were subjected to the statistical analysis of 
variance and the treatment means were compered for significant differences using the LSD at $p=0.05$ and $p=0.01$. The MSTAT_C (version 2.10) computer program was used to perform all the analysis of variance in an agreement with the procedure outlined by Steel and Torrie (1982).

\section{Water Relations} use 'WCU'

1-Actual water consumptive

Water consumptive use was determined via soil samples from the sub.sub plots just before each irrigation and $48 \mathrm{~h}$ later besides at harvest, in $15 \mathrm{~cm}$ segments along the $60 \mathrm{~cm}$ depth of the soil. The WCU was calculated according to Israelsen and Hansen (1962) as follows:

$W C U=(Q 2-Q 1) * E R Z D * B d * 42$

\section{Where:}

$\mathrm{CU}=$ actual consumptive use $\left(\mathrm{m}^{3} / \mathrm{fed}\right)$

ERZD = effective root zoon depth.

(m)

Bd = bulk density of soil $\left(\mathrm{Mg} \mathrm{m}^{-3}\right)$

$\mathrm{Q}_{2} \quad=$ the soil moisture two days after irrigation $(\% \mathrm{w} / \mathrm{w})$.

$\mathrm{Q}_{1} \quad=$ the soil moisture before next irrigation $(\% \mathrm{w} / \mathrm{w})$.

\section{2- Water use efficiency (WUE)}

Water use efficiency in the present work, refers to the amount of wheat grains $(\mathrm{kg})$ produced due to one $\mathrm{m}^{3}$ of consumed water which, estimated according to Vites (1965) as follow

WUE $=\frac{\text { Grain yield }(\mathrm{kg} / \mathrm{fed})}{\text { Consumptive use }(\mathrm{m} 3 / \mathrm{fed})}$

Results and Discussion

1. Growth and Yield Parameters

1.1 Grain weight of 5 spikes (g):

1.1.1 Effect of sowing date

(A): Table 4-a and 4-b showed that delaying sowing date by two weeks increased the grain weight of 5 spikes in the three seasons. The grain weight of 5 spikes of were $12.509,13.256$, and $15.460 \mathrm{~g}$ was produced by the late sowing date (S2) at the $5^{\text {th }}$ of December and $11.982,12.595$ and $14.480 \mathrm{~g}$ from S1 at the $20^{\text {th }}$ of November during the three growing seasons i.e., 2012/13, 2013/14, and2014/15, respectively. Delaying the cultivation date by 15 days increased the three season's average grain weight of 5 spikes from 13.014 to $13.742 \mathrm{~g}$ $(5.55 \%)$.

1.1.2 Effect of irrigation regime (B): Table 4-a and 4-b also revealed that, the irrigation treatments significantly increased the grain weight of 5 spikes. The highest values for grain weight of 5 spikes was given by the irrigation at 21 days interval (I1) during the three growth seasons. The grain weight of 5 spikes were as $13.994,14.580$ and $17.974 \mathrm{~g}$ (I1), 11.740, 12.778 and 14.279 (I2), $11.003,11.419$ and $12.657 \mathrm{~g}$ (I3) during the three growing seasons, 2012/13, 2013/14, and 2014/15, respectively. Grain weight of 5 spikes was increased by $32.6 \%$ and $10.6 \%$ by shortening the irrigation interval from 35 day to 21 and 28 days, respectively.

\subsubsection{Effect of wheat cultivars}

(C): Wheat cultivars showed highly significant differences in the grain weight of 5 spikes, as shown in Table 4-a and 4-b. Wheat cultivar Shandaweel-1(V1) gave the best results of grain weight of $12.840,13.686$ and $15.60 \mathrm{gm} / 5$ spikes during 2012/13, $2013 / 14$, and 2014/15 seasons, respectively. Shandaweel-1 variety and Sides-12 produced grain weight of 
14.042 and $13.223 \mathrm{gm} / 5$ spikes compared to $12.872 \mathrm{gm} / 5$-spikes from Giza 168. The increase in Shandaweel-1 was $9.089 \%$ over Giza 168 . The grain weight of 5 spikes of Shandaweel-1 increased gradually from 2012 through 2015 and was better than the other two varieties.

1.1.4 A x B Interaction: The interaction between sowing date and irrigation treatments produced significant differences in the grain weight of 5-spikes through the three seasons. The highest values of the grain weight of 5spikes were produced form the interaction between the second sowing date and irrigation at 21 days interval (S2*I1).

1.1.5 A x C Interaction: Shandaweel-1 with the second sowing date produced the best interaction during the three growing seasons. The highest values for grain weight of 5 spikes of that interaction were 13.193,
14.070 and $16.128 \mathrm{gm} / 5$ spikes grain, through 2012/13, 2013/14, and2014/15 seasons, respectively.

1.1.6 B x C Interaction: Highly significant differences were resulted from the irrigation interval of 21 days (I1) and Shandaweel-1. The highest values for grain weight of 5 -spikes were $14.897,16.008$, and 19.308 $\mathrm{gm} / 5$-spikes during 2012/13, $2013 / 14$, and 2014/15 seasons, respectively.

\subsubsection{A x B x C Interaction:} Shandaweel-1irrigated every 21 days which cultivated on the $5^{\text {th }}$ of Dec. produced high significant values of grain weight of 5 spikes.

The obtained results showed a steady increase in the average of the grain weight of 5 spikes through the three seasons. The decrease in the Max temperature during 2014/15 than $2012 / 13$ increased the grain weight of 5 spikes by $22.24 \%$.

Table-4-a. Grain weight of 5 spikes (g) during three years for the three verities, three irrigation regimes and two swing dates.

\begin{tabular}{|c|c|c|c|c|c|c|c|c|c|}
\hline Seasons & V1 & V2 & V3 & I1 & I2 & I3 & S1 & S2 & Mean \\
\hline $\mathbf{2 0 1 2} / \mathbf{1 3}$ & 12.840 & 11.675 & 12.222 & 13.994 & 11.740 & 11.003 & 11.982 & 12.509 & 12.246 \\
\hline $\mathbf{2 0 1 3} / \mathbf{1 4}$ & 13.686 & 12.404 & 12.687 & 14.580 & 12.778 & 11.419 & 12.595 & 13.256 & 12.926 \\
\hline $\mathbf{2 0 1 4 / 1 5}$ & 15.601 & 14.538 & 14.772 & 17.974 & 14.279 & 12.657 & 14.480 & 15.460 & 14.970 \\
\hline Mean & 14.042 & 12.872 & 13.227 & 15.516 & 12.932 & 11.693 & 13.019 & 13.742 & 13.380 \\
\hline \% \pm & 9.089 & 0.000 & 2.755 & 32.7 & 10.6 & 0.000 & 0.000 & 5.551 & \\
\hline
\end{tabular}

Where: (A) FACTOR s1, and S2 $=$ Sowing on $20^{\text {th }}$ November, and $5^{\text {th }}$ December. (B)FACTOR I1, I2andI3 =Irrigation regime 21, 28 and35days.(C) FACTOR, V1, V2 andV3 = wheat cultivars I.e., Shandaweel-1, GIza-168 and SIds-

\subsection{Seed index (g/1000 grains):}

\subsubsection{Effect of sowing date} (A): Results in Table 5-a and 5-b indicated that, delaying the cultivation date by two weeks did not reduce the seed index significantly but it produced $1.34 \%$ increase in the seed index

\subsubsection{Effect of irrigation re-} gime (B): The results in Table 5-a and 5-b showed that the irrigation regimes significantly affected on the seed index in the three studied seasons, where the best results of seed index were obtained from the irrigation (I1) at 21days interval with values of $46.125,43.386$, and 45.655 
gm/1000 grains, for 2012/13, 2013/14 and 2014/15 seasons, respectively. Seed index was increased by $14.943 \%$ and $7.125 \%$ by shortening the irrigation interval from 35 day to 21 and 28 days, respectively.

\subsubsection{Effect of wheat cultivars}

(C): Data in Table 5-a and 5-b indicated that the seed index was significantly affected by wheat cultivars. The highest values of 44.108, 41.939, and $43.439 \mathrm{gm} / 1000$ grains, were gained from Shandaweel-1 cultivar (V1) during 2012/13, 2013/14 and $2014 / 15$ seasons, respectively. The seed index of Shandaweel-1 of $4.27 \%$ was higher than Seds-12 and 3.64\% higher than Giza-168.

1.2.4 A x B Interaction: The interaction between sowing date and irrigation treatments produced significant differences in the seed index through the three seasons. The highest values of seed index were produced form the interaction between the second sowing date with irrigation at 21 days interval (S2*I1) namely, 46.85, 43.84, and 46.08 gm/1000grin , from 2012/13, 2013/14 and 2014/15 seasons, respectively.

1.2.5 A x C Interaction: Data in Table 5-a and 5-b revealed no significant effects were found on seed index values due to the interaction between sowing date and wheat cultivars.

1.2.6 B x C Interaction: The interaction between irrigation regime and wheat cultivars had a significant effect on seed index. The highest values of seed index were produced from irrigating Shandaweel-1 wheat cultivar (V1) every 21 days (I1) with value of $47.480,43.863$, and 46.762 $\mathrm{gm} / 1000$ grin, respectively, through 2012/13, 2013/14 and 2014/15 seasons, respectively.

\subsubsection{A x B x C Interaction:}

The highest values of seed index were optioned from the interaction of the second sowing date at $5^{\text {th }}$ December of Shandaweel-1 irrigated every 21 days interval with value of 48.340 , 44.387 and $47.317 \mathrm{~g} / 1000$ grains, during 2012/13, 2013/14 and 2014/15, respectively.

Table-5-a. Seed Index (g/1000grains) during three years for the three verities, three irrigation regimes and two swing dates.

\begin{tabular}{|c|c|c|c|c|c|c|c|c|c|}
\hline Sea- & V1 & V2 & V3 & I1 & I2 & I3 & S1 & S2 & Mean \\
\hline $\mathbf{2 0 1 2} / \mathbf{1}$ & 44.108 & 42.235 & 41.708 & 46.125 & 42.922 & 39.003 & 42.281 & 43.086 & 42.684 \\
\hline $\mathbf{2 0 1 3} / \mathbf{1}$ & 41.939 & 40.873 & 40.868 & 43.386 & 41.260 & 39.034 & 41.051 & 41.402 & 41.227 \\
\hline $\mathbf{2 0 1 4 / 1}$ & 43.439 & 41.953 & 41.610 & 45.655 & 41.790 & 39.557 & 42.043 & 42.625 & 42.334 \\
\hline Mean & 43.162 & 41.687 & 41.395 & 45.055 & 41.991 & 39.198 & 41.792 & 42.371 & 42.081 \\
\hline \% \pm & 4.268 & 0.705 & 0.000 & 14.943 & 7.125 & 0.000 & 0.000 & 53.929 & \\
\hline
\end{tabular}

Where: (A) FACTOR S1, and S2 $=$ Sowing on $20^{\text {th }}$ November, and $5^{\text {th }}$ December. (B)FACTOR I1, I2 and I3 =Irrigation regime 21,28 and 35days. (C) FACTOR, V1, V2 andV3 = wheat cultivars I.e., Shandaweel-1, GIza-168 and SIds-12

\subsection{Total biological yield (ton/fed):}

1.3.1 Effect of sowing date

(A): Data in Table 6-a and 6-b, revealed that the total biological yield was significantly effected by sowing date. The best values of the total biological yield of 7.389, 6.092 and 5.852 ton/fed resulted from the sec- 
ond sowing date at $5^{\text {th }}$ December in. Total biological yield increased by $7.98 \%$ with the second sowing (date $5^{\text {th }}$ December) over the first sowing date $\left(20^{\text {th }}\right.$ November).

\subsubsection{Effect of irrigation re-} gime (B): Data recorded in Table 6-a and 6-b indicated that the total biological yield was significantly increased by shortening the irrigation intervals with values, of 5.563, 6.190, and 6.865 ton/fed for 35,28 and 21 days irrigation interval, respectively. Irrigation every 21days gave the highest values of the total biological yield of $7.897,6.331$ and 5.852 ton/fed through the three seasons i.e., 2012/13, 2013/14 and 2014/15. Total biological yield significantly increased with decreasing the irrigation interval from 35 days by one and two weeks by $11.270 \%$ and $23.405 \%$

\subsubsection{Effect of wheat culti-} $\operatorname{vars}(\mathbf{C})$ : Data in Table 6-a and 6-b shown that, Shandaweel-1 produced significant higher yield than the other two cultivar. Total biological yield of wheat cultivars Shandaweell and Giza168 was increased by $4.698 \%$ and $0.421 \%$ Sids 12 , respectively, compared of Sids 12 .

\subsubsection{Effect of $A \times B$ interac-}

tion: The total biological yield values were significantly affected by the interactions between sowing date and irrigation regime, where the sowing date on 5th of Dec. with irrigation every 21 treatment recorded the highest values of total biological yield 8.709 and 6.628 ton/ fed) in both the first and second seasons (2012/13 and $2013 / 14)$, respectively. The interaction of the first sowing date with irri- gation treatment interval21 days had the highest value of total biological yield $(6.460$ ton $/$ fed $)$ in the last season 2014/15.

\subsubsection{Effect of $A \times C$ interac-}

tion: The total biological yield of Shandaweel-1 sown on the $5^{\text {th }}$ of Dec. as an average of three years was better than the other two wheat cultivars and sowing dates.

\subsubsection{Effect of $B \times C$ interac-} tion: Shandaweel-1 wheat cultivar with irrigation at 21 days significantly affected the total biological. The biological yield obtained from interaction between the irrigation intervals at 21 days with Shandaweel-1 were $8.254,6.512$ and 6.549 ton /fed, during 2012/13, 2013/14 and2014/15 seasons, respectively.

\subsubsection{Effect A x B x C interac-} tion: The triple interaction of sowing date with irrigation regime and wheat cultivars showed significant effects on total biological yield. Shandaweel1 , irrigated every 21 days which sown on the $5^{\text {th }}$ of Dec. produced the highest significant value of total biological yield of 8.893 ton/fed.

The total biological yield was reduced from $2012 / 13$ to $2014 / 15$, growth seasons by $18.83 \%$, due to temperature reduction by about on degree. In contrast, the grain weight of 5 spikes showed a steady increase in the average of the grain weight of the 5spikes through the three seasons and that was supposed to be due to the decrease in the Max temperature during 2014/15 than 2012/13. The cold weather enhances the grain filling which overcomes the vegetative growth and hay ratio. 
Table-6-a. Total biological yield (ton/fed) during three years for the three verities, three irrigation regimes and two swing dates.

\begin{tabular}{|c|c|c|c|c|c|c|c|c|c|}
\hline Sea- & V1 & V2 & V3 & I1 & I2 & I3 & S1 & S2 & MEA \\
\hline $\mathbf{2 0 1 2} / \mathbf{1}$ & 7.014 & 6.770 & 6.809 & 7.884 & 6.838 & 5.871 & 6.340 & 7.389 & 6.865 \\
\hline $\mathbf{2 0 1 3} / \mathbf{1}$ & 6.190 & 5.791 & 5.949 & 6.331 & 5.928 & 5.671 & 5.862 & 6.092 & 5.977 \\
\hline $\mathbf{2 0 1 4} / \mathbf{1}$ & 5.962 & 5.822 & 5.547 & 6.381 & 5.803 & 5.147 & 5.701 & 5.852 & 5.777 \\
\hline Mean & 6.389 & 6.128 & 6.102 & 6.865 & 6.190 & 5.563 & 5.968 & 6.444 & 6.206 \\
\hline \% \pm & 4.698 & 0.421 & 0.000 & 23.405 & 11.270 & 000 & 0.000 & 7.980 & \\
\hline
\end{tabular}

Where: (A) FACTOR s1, and S2 $=$ Sowing on $20^{\text {th }}$ November, and $5^{\text {th }}$ December. (B)FACTOR I1, I2andI3 =Irrigation regime 21, 28 and 35days. (C) FACTOR, V1, V2 andV3 = wheat cultivars I.e., Shandaweel-1, GIza-168 and SIds-1

\subsection{Grain yield ( $\mathrm{kg} /$ fed).}

Data in Table 7-a and 7-b, present the results of grain yield.

\subsubsection{Effect of sowing date} (A): Delaying the sowing date 15 days from $20^{\text {th }}$ November to $5^{\text {th }}$ December caused $17.477 \%$ increase in wheat grain yield. This increase was significant. The best values for grain yield were 2314.8, 2467.9 and 2474.7 $\mathrm{kg} / \mathrm{fed}$., that were recorded for the second sowing date $5^{\text {th }}$ December and $1841.8,2181.4$ and $2154.6 \mathrm{~kg} / \mathrm{fed}$., for the $20^{\text {th }}$ of Nov. during the three respective seasons 2012/13, 2013/14 and2014/15. The average grain yield produced from the late sowing date was $2419.2 \mathrm{~kg} / \mathrm{fed}(5760 \mathrm{~kg} / \mathrm{ha})$.

\subsubsection{Effect of irrigation re-} gime (B): The grain yield was significantly affected by the irrigation regime interval. Grain yield values were increased by using irrigation treatment interval of 21days which gave the highest values for grain yield of 2735.2, 2491.4 and 2579.7 $\mathrm{kg} / \mathrm{fed}$ for 2012/13, 2013/14 and 2014/15 seasons, respectively. The grain yield increased due to increasing the soil moisture. These results are in agreement with those reported by Khail et al, (2005) and ElMarsafawy (2000). Increasing the irrigation interval by one and two weeks reduced the grain yield by
$15.5 \%$ and $24.4 \%$, respectively. Therefor 21days irrigation interval would be the best irrigation schedule for max grain weight. Metin-Sezen and Attila-Yazar (2006) in the arid Southeast Anatolia of Turkey, recorded that shortening the irrigation intervals (7, 14 and 21 days) increased the grain yield, compared with prolonged irrigation intervals (35 days).Decreasing the irrigation interval by two or one week increased the grain yield significantly by $32.957 \%$ and $12.367 \%$. There for, using 21 days interval, would be the best irrigation scheduling for highs grain yield in Sohag.

\subsubsection{Effect of wheat cultivars}

(C): The highest values of grain yield of $2160.4,2455.4$ and $2332.7 \mathrm{~kg} / \mathrm{fed}$ were gained from Shandaweel-1, through 2012/13, 2013/14 and 2014/15, seasons, respectively. The grain yield of the three variety namely Shandaweel-1, Giza168, and Sides-12 were 2316.2, 2242.4, and $2159.0 \mathrm{~kg} / \mathrm{fed}$ respectively. The increase in the grain yield of Shandaweel1 was $7.278 \%$ compared to Sides-12.

\subsubsection{Effect of $A \times$ B interac-} tion: The grain yield values were significantly affected by the interactions between sowing date and irrigation regime. The highest values of 
grain yield of $3150.3,2656.31$ and $2676.8 \mathrm{~kg} /$ fed were produced by sowing wheat on 5th Dec, and irrigating it every 21 days. During the growing seasons of 2012/13, 2013/14 and 2014/15, respectively. The lowest grain yield was resulted from interval of 35 days and $20^{\text {th }}$ of Nov. date.

\subsubsection{Effect of $A \times C$ interac-} tion: The highest grain yield was produced when wheat cultivar of Shandaweel-1 (V1) was sown in the late sowing date of $5^{\text {th }}$ December (S2), in the first 2012/13 and second 2013/14 seasons (2475.2 and 2576.2 $\mathrm{kg} /$ fed), respectively. However, Giza186 sown on the 5th of Dec. had the best value of grain yield in the last season 2014/15 with value of
$2570.7 \mathrm{~kg} / \mathrm{fed}$. This result may be due to the interaction between genetic coefficients with the weather condition.

\subsubsection{Effect of B x C interac-} tion: Irrigation at 21 days with Shandaweel-1 wheat cultivar recorded the best values of grain yield i.e. 2861.7, 2573.0 , and $2638.5 \mathrm{~kg} / \mathrm{fed}$ through 2012/13, 2013/14 and 2014/15 seasons, respectively.

\subsubsection{Effect of A x B x C inter-} action: The highest result for grain yield of 3290.6, was obtained by Shandaweel-1(V1) irrigated every 21 days (I1) at the second sowing $5^{\text {th }}$ December (S2) date. The grain yield increased in the second and third year by 11.86 and $11.37 \%$ respectively.

Table-7-a. Grain yield (kg /fed) during three years for the three verities, three irrigation regimes and two swing dates.

\begin{tabular}{|c|c|c|c|c|c|c|c|c|c|}
\hline Seasons & V1 & V2 & V3 & I1 & I2 & I3 & S1 & S2 & Mean \\
\hline $2012 / 13$ & 2160.472 & 2102.117 & 1972.461 & 2722.372 & 1976.728 & 1535.950 & 1841.807 & 2314.893 & 2078.35 \\
\hline 2013/14 & 2455.422 & 2266.983 & 2251.711 & 2456.872 & 2301.544 & 2215.700 & 2181.485 & 2467.926 & 2324.71 \\
\hline $2014 / 15$ & 2332.778 & 2358.222 & 2253.089 & 2580.167 & 2279.533 & 2084.389 & 2154.615 & 2474.778 & 2314.70 \\
\hline Mean & 2316.22 & 2242.44 & 2159.09 & 2586.47 & 2185.94 & 1945.35 & 2059.30 & 2419.20 & 2239.25 \\
\hline$\% \pm$ & 7.278 & 3.861 & 0.000 & 32.957 & 12.367 & 0.000 & 0.000 & 17.477 & \\
\hline
\end{tabular}

\subsection{Straw yield (ton/fed)}

Data in Tables 8-a, and 8-b includes the results of the wheat straw, yield.

\subsubsection{Effect of sowing Date:} The straw yield produced from sowing dates of $20^{\text {th }}$ of Nov. and $5^{\text {th }}$ of Dec. were 4.492 , and 4.989 tons/fed. in 2012,30657 and 3.624 tons/fed. in 2014 , and 30367 and 30537 tons/fed. in 2015. The straw yield values were higher with the late sowing while the straw yield was going down growing with seasons from 2012/13, to 2014/15 growth seasons while the grains yield had an increasing trend.

1.5.2 Effect of irrigation regime: Data recorded in Table 8-a and 8-b indicated that the straw yield was significantly affected by the irrigation regime interval. Straw yield values were increased by reducing the irrigation interval to 21 days which gave the highest values for straw yield of $5.148,3.839$ and 3.802 tons/fed in the three respective seasons i.e. 2012/13, 2013/14 and 2014/15. Metin-Sezen and Attila-Yazar (2006 reported similar results.

1.5.3 Effect of wheat cultivars: The straw yield values produced from Shandaweel-1 cultivar were significantly higher than the other two cultivars with values of $4.835,3.735$ and 3.626 ton/fed, through 2012/13, 
2013/14 and 2014/15 seasons, respectively.

\subsubsection{Effect of $A \times$ b interac-} tion: The interaction between the second sowing date and irrigation treatment interval 21 days recoded the highest values of straw yield (5.533 and $3.967 \mathrm{ton} / \mathrm{fed}$ ) in both the first and second seasons (2012/13 and 2013/14), respectively, the interaction of the first sowing date with irrigation treatment interval 21 days recorded the highest value of total yield (3.971 ton /fed) in the last season 2014/15.

\subsubsection{Effect of A x C interac-} tion: Results in Table 8-a and 8-b indicated that the values of straw yield were significantly affected by the interaction between the sowing date and wheat cultivars.

\subsubsection{Effect of B x C interac-}

tion: Data illustrated in table 8-a and 8-b showed a significant effect on the straw yield due to the interaction between the irrigation regimes and wheat cultivars. The interaction between the irrigation treatment interval 21 days (I1) and wheat cultivar Shandaweel $1(\mathrm{~V} 1)$ had the highest values of straw yield $(5.353,3.939$ and 3.917 ton /fed) in $(2012 / 13,2013 / 14$ and2014/15) seasons, respectively.

\subsubsection{Effect of A x B x C inter-} action: The triple interaction showed that Sids-12 sown on 5 Dec. with the irrigation regime every 21 produced significant higher straw yields through the first and second seasons, while Shandweel-1 produced the highest straw yield when sown on the $20^{\text {th }}$ of Nov. and irrigated every 28 days.

Table-8-a. Straw yield (ton/fed) during three years for the three verities, three irrigation regimes and two swing dates.

\begin{tabular}{|c|c|c|c|c|c|c|c|c|c|}
\hline Sea- & V1 & V2 & V3 & I1 & I2 & I3 & S1 & S2 & Mean \\
\hline $\mathbf{2 0 1 2} / \mathbf{1}$ & 4.835 & 4.662 & 4.724 & 5.148 & 4.741 & 4.332 & 4.492 & 4.989 & 4.741 \\
\hline $\mathbf{0 2 0 1 3} /$ & 3.735 & 3.522 & 3.664 & 3.839 & 3.629 & 3.454 & 3.657 & 3.624 & 3.641 \\
\hline $\mathbf{2 0 1 4 / 1}$ & 3.626 & 3.451 & 3.279 & 3.802 & 3.514 & 3.041 & 3.537 & 3.367 & 3.452 \\
\hline Mean & 4.065 & 3.878 & 3.889 & 4.263 & 3.961 & 3.609 & 3.895 & 3.993 & 3.944 \\
\hline \% \pm & 4.831 & 0.009 & 0.284 & 18.121 & 9.763 & 0.000 & 0.000 & 2.525 & \\
\hline
\end{tabular}

Where: (A) FACTOR s1, and S2 $=$ Sowing on $20^{\text {th }}$ November, and $5^{\text {th }}$ December. (B)FACTOR I1, I2 and I3 = Irrigation regime 21, 28 and35days.(C) FACTOR, V1,V2 andV3 = wheat cultivars I.e., Shandaweel-1, GIza168 and SIds- 12

\section{Water Relations}

\subsection{Actual water consumptive} use (WCU, $\mathbf{m}^{3} /$ fed).

Evapotranspiration is the combination of two processes, evaporation and transpiration. Evaporation is the direct evaporation of water from the soil surface and/or from the plant surface. Transpiration is the flow of water vapor from the interior of the plant to the atmosphere (Jones et al, 1984). Results in Table 9-a and 9-b showed that the seasonal water con- sumptive use (ETa) was increased as Etc with the increased number of irrigations and the soil moisture was more available for extraction by plant roots and as well as soil surface evaporation where the value of the ETc for irrigation treatment 21 day heights than the 28, and 35 days irrigation treatment. Water consumptive use was reduced by $6.64 \mathrm{~m}^{3}$ in $2014 / 15$ season compared to $2012 / 13$ and 2013/14 seasons. due to the change in the $\mathrm{T}^{0}$ Max by $1.1 \mathrm{C}^{0}$ in 
2014/15 season compared by 2012/13 and 2013/14 seasons, the EP also changed in these seasons by 4.43 , $4.63,4.12 \%$

2.1.1 Factor (A): Effect of sowing date (A), the WCU maximum value was predicted by the first sowing date $\mathrm{S} 1$ in all studied seasons, With respect to sowing date, The WCU in 2012/13, 2013/14 and 2014/15 for S1(1908, 1857 and 1778 $\mathrm{m}^{3} /$ fed)for $2012 / 13$, respectively, in same respective WCU results for S2 were $\left(1855,1879\right.$, and $1777 \mathrm{~m}^{3} /$ fed). These results indicate that ETa values with early sowing date, whereas delaying sowing date decreased WCU values. Due to shortage growth season under delayed sowing date caused in minimize develop roots growth as well as decrease water uptake by plant. These results were pointed out by (Hussein et al,. 1990) who reported that sowing wheat at late November in $\left(20^{\text {th }}\right.$ and $\left.28^{\text {th }}\right)$ generally increases crop $\mathrm{CU}$ values when compared by swing at December. Delaying the sowing date by 15 days to $5^{\text {th }}$ December reduced the water consumptive use.

2.1.2 Factor (B): Effect of irrigation regime(B). The highest $\mathrm{WCU}$ values were predicted by I1, water consumptive use was increased as ETc with the increased number of irrigations and the soil moisture was more available for extraction by plant roots and as well as soil surface evaporation where the value of the ETc for irrigation treatment 21 day heights than the 28 , and 35days irrigation treatment. The WCU value in the first season 2012/13 was (2194, 1874 , and $1620 \mathrm{~m}^{3} / \mathrm{fed}$ ) for irrigation treatment I1, I2 and I3, respectively.
The same respective in 2013/14 and 2014/15 WCU value were (2104, 1912 and $1588 \mathrm{~m}^{3} / \mathrm{fed}$ ) in succession. Irrigation every 28 days and 21 days increased the consumptive use more than the irrigation interval 35 days by $16.6 \%$ and $33.1 \%$.

2.1.3 Factor (C): Effect of wheat cultivars $(C)$, The data in Table 9-a and 9-b showed that the wheat cultivar Giza168, V2 recorded the highest value for WCU in these study, and the least value was given by seidss12. The cultivar Giza168 used water $5.3 \%$ more than Sides 12 while Shandaweel1 used $1.4 \%$ water more than Sides12, that is due to the genetic fraction of each variety .

2.1.4 A x B Interaction: The interaction between sowing date and irrigation regimes, as shown in Table 9-a and 9-b pointed out that, the WUC gave different results, while, the interaction between sowing date and irrigation treatment interval 35 days (I3) gave the minimum value of WCU.

2.1.5 A x C Interaction: The interaction $\mathrm{S} 2 * \mathrm{~V} 2$ recorded the highest $\mathrm{WCU}$ value in most results.

2.1.6 B x C Interaction: The interaction between irrigation regime and wheat cultivars as shown in Table 9-a and 9-b pointed out that the WCU value was increased by short irrigation to 21days interval (I1) with wheat cultivar Giza168 (V2).

2.1.7 A x B x C Interaction: The general interaction of these studied treatment $(\mathrm{S} 1 * \mathrm{I} 1 * \mathrm{~V} 2, \mathrm{~S} 1 * \mathrm{I} 1 \mathrm{~V} 1$, and $\mathrm{S} 1 * \mathrm{I} 1 \mathrm{~V} 2)$ recorded the highest WCU value in 2012/13, 2013/14 and 2014/15. While, the WCU was (2445, 2156 , and $2124 \mathrm{~m}^{3} /$ fed), respectively. 
Table-9-a Actual (measured) water consumptions during three years for the three verities, three irrigation regimes and two swing dates

\begin{tabular}{|c|c|c|c|c|c|c|c|c|c|}
\hline Sea- & V1 & V2 & V3 & I1 & I2 & I3 & S1 & S2 & Mean \\
\hline $\mathbf{2 0 1 2} / \mathbf{1}$ & 1877 & 1968 & 1844 & 2194 & 1874 & 1620 & 1908 & 1885 & 1896 \\
\hline $\mathbf{2 0 1 3} / \mathbf{1}$ & 1857 & 1908 & 1839 & 2104 & 1915 & 1839 & 1857 & 1879 & 1868 \\
\hline $\mathbf{2 0 1 4} / \mathbf{1}$ & 1763 & 1830 & 1739 & 2030 & 1778 & 1525 & 1778 & 1777 & 1778 \\
\hline Mean & 1832 & 1902 & 1807 & 2109 & 1848 & 1585 & 1848 & 1847 & 1847 \\
\hline \% \pm & 1.383 & 5.238 & 0.000 & 33.100 & 16.578 & 0.000 & 0.036 & 0.000 & \\
\hline
\end{tabular}

Where: (A) FACTOR s1, and S2 $=$ Sowing on $20^{\text {th }}$ November, and $5^{\text {th }}$ December (B) FACTOR I1, I2andI3 =Irrigation regime 21, 28 and35days.(C) FACTOR, V1, V2 andV3 = wheat cultivars, Shandaweel-1, GIza-168 and SIds-12

\subsection{Water use efficiency (WUE):}

Table 10-a and 10-b shows the results for WUE witch indicated that:

2.2.1 Factor (A): The second sowing date of $5^{\text {th }}$ December (S2), recorded the best WUE value through the three seasons. The WUE values was 0.963 , and $1.256 \mathrm{~kg}$ of wheat $/ \mathrm{m}^{3}$ for S1 and S2 in the first season 2012/13, respectively, while in the successive seasons 2013/14 and 2014/15 the WUE value for S1 and $\mathrm{S} 2$ were 1.200 , and $1.323 \mathrm{~kg} / \mathrm{m}^{3}$, 1.217 , and $1.409 \mathrm{~kg} / \mathrm{m}^{3}$, respectively .

2.2.2 Factor (B): Irrigation every 21 day interval (I1) in the first season $(2012 / 13)$ was the best. However, WUE values increased with irrigation at 35 days interval (I3) in 2013/14 and 2014/15. These are due to the decrease in the applied water consumed (I3). These results matched with those reported by El-Marsafawy (2000) She found that the highest WUE value for wheat was achieved as irrigation practiced according at 1.0 EPC.
2.2.3 Factor (C): Shandaweel1(V1) gave the best values for WUE in all growth seasons.

2.2.4 A x B Interaction: The maximum WUE was given by the interaction of the second sowing date with the irrigation at 21 days interval (S2*I1) only in the first season $(2012 / 13)$, but the interaction between the second sowing date and the irrigation at 35 days interval $(\mathrm{S} 2 * \mathrm{I} 3)$ recorded the highest WUE value in $2013 / 14$ and $2014 / 15$ as shown in Table 5 .

2.2.5 A x C Interaction: The interaction between wheat cultivar Shandaweel 1and second sowing date $5^{\text {th }}$ December $(\mathrm{S} 2 * \mathrm{~V} 1)$ gave the best WUE values for all seasons.

2.2.6 B x C Interaction: WUE values increased with using irrigation treatment of 35 days interval with wheat cultivar Shandaweel $1(\mathrm{I} 3 * \mathrm{~V} 1)$.

2.2.7 The effect of the triple interaction $\left(A^{*} \mathbf{B} * \mathbf{C}\right)$ : The highest WUE was with sowing wheat cultivar Shandaweel $1(\mathrm{~V} 1)$, in $5^{\text {th }}$ December (S2), using irrigation treatment interval of 35 days (I3). 
Table -9-a. Actual Water use efficiency (WUE) during three years for the three verities, three irrigation regimes and two swing dates

\begin{tabular}{|c|c|c|c|c|c|c|c|c|c|}
\hline Sea- & V1 & V2 & V3 & I1 & I2 & I3 & S1 & S2 & Mean \\
\hline $\mathbf{2 0 1 2} / \mathbf{1}$ & 1.145 & 1.065 & 1.117 & 1.251 & 1.126 & 0.951 & 0.964 & 1.255 & 1.110 \\
\hline $\mathbf{2 0 1 3} / \mathbf{1}$ & 1.340 & 1.196 & 1.250 & 1.183 & 1.221 & 1.382 & 1.201 & 1.323 & 1.262 \\
\hline $\mathbf{2 0 1 4 / 1}$ & 1.332 & 1.302 & 1.307 & 1.272 & 1.289 & 1.380 & 1.219 & 1.409 & 1.314 \\
\hline Mean & 1.272 & 1.188 & 1.225 & 1.235 & 1.212 & 1.238 & 1.128 & 1.329 & 1.229 \\
\hline \% \pm & 7.099 & 0.000 & 3.086 & 1.925 & 0.000 & 2.118 & 0.000 & 17.819 & \\
\hline
\end{tabular}

Where: (A) FACTOR s1, and S2 $=$ Sowing on $20^{\text {th }}$ November, and $5^{\text {th }}$ December, (B)FACTOR I1, I2andI3 $=$ Irrigation regime 21, 28 and35days. (C) FACTOR, V1, V2 andV3 = wheat cultivars, Shandaweel-1, GIza168 and SIds- 12

Table -4-b. Effect of different sowing dates and irrigation regimes on grain weight /5 spikes ( $g$ ) of some wheat varieties under Sohag governorate conditions

\begin{tabular}{|c|c|c|c|c|c|c|c|c|c|c|c|c|c|}
\hline \multirow{4}{*}{$\begin{array}{c}\text { Sowing } \\
\text { date } \\
\text { (A) }\end{array}$} & \multirow{4}{*}{$\begin{array}{c}\text { Irrigatio } \\
\text { regime } \\
\text { (B) }\end{array}$} & \multicolumn{12}{|c|}{ Grain weight /5 spikes(g) } \\
\hline & & \multicolumn{4}{|c|}{ 2012/13 season } & \multicolumn{4}{|c|}{ 2013/14 season } & \multicolumn{4}{|c|}{ 2014/15 season } \\
\hline & & \multicolumn{3}{|c|}{ Varieties $(\mathrm{C})$} & \multirow{2}{*}{ Mean } & \multicolumn{3}{|c|}{ Varieties (C) } & \multirow{2}{*}{ Mean } & \multicolumn{3}{|c|}{ Varieties (C) } & \multirow{2}{*}{ Mean } \\
\hline & & V1 & V2 & V3 & & V1 & V2 & V3 & & V1 & $\mathrm{V2}$ & V3 & \\
\hline \multirow{3}{*}{ S1 } & I1 & 13.970 & 12.673 & 12.990 & 13.211 & 14.967 & 13.000 & 13.600 & 13.856 & 17.880 & 16.077 & 16.400 & 16.786 \\
\hline & I2 & 12.017 & 11.517 & 11.670 & 11.734 & 12.843 & 12.450 & 12.633 & 12.642 & 14.300 & 13.753 & 14.190 & 14.081 \\
\hline & I3 & 11.473 & 10.917 & 10.613 & 11.001 & 12.093 & 11.293 & 10.477 & 11.288 & 13.040 & 12.850 & 11.830 & 12.573 \\
\hline \multicolumn{2}{|c|}{ Mean } & 12.487 & 11.702 & 11.758 & 11.982 & 13.301 & 12.248 & 12.237 & 12.595 & 15.073 & 14.227 & 14.140 & 14.480 \\
\hline \multirow{3}{*}{ S2 } & I1 & 15.823 & 13.267 & 15.243 & 14.778 & 17.050 & 13.597 & 15.267 & 15.304 & 20.737 & 17.660 & 19.090 & 19.162 \\
\hline & $\mathbf{I 2}$ & 12.610 & 10.577 & 12.050 & 11.746 & 13.173 & 12.573 & 12.993 & 12.913 & 14.730 & 14.017 & 14.687 & 14.478 \\
\hline & I3 & 11.147 & 11.100 & 10.767 & 11.004 & 11.987 & 11.510 & 11.153 & 11.550 & 12.917 & 12.870 & 12.437 & 12.741 \\
\hline \multicolumn{2}{|c|}{ Mean } & 13.193 & 11.648 & 12.687 & 12.509 & 14.070 & 12.560 & 13.138 & 13.256 & 16.128 & 14.849 & 15.404 & 15.460 \\
\hline \multirow{3}{*}{$B * C$} & I1 & 14.897 & 12.970 & 14.117 & 13.994 & 16.008 & 13.298 & 14.433 & 14.580 & 19.308 & 16.868 & 17.745 & 17.974 \\
\hline & I2 & 12.313 & 11.047 & 11.860 & 11.740 & 13.008 & 12.512 & 12.813 & 12.778 & 14.515 & 13.885 & 14.438 & 14.279 \\
\hline & I3 & 11.310 & 11.008 & 10.690 & 11.003 & 12.040 & 11.402 & 10.815 & 11.419 & 12.978 & 12.860 & 12.133 & 12.657 \\
\hline \multicolumn{2}{|c|}{$\operatorname{Mean}(C)$} & 12.840 & 11.675 & 12.222 & & 13.686 & 12.404 & 12.687 & & 15.601 & 14.538 & 14.772 & \\
\hline
\end{tabular}

Where: (A) FACTOR s1, and S2 =Sowing on $20^{\text {th }}$ November, and $5^{\text {th }}$ December. (B)FACTOR I1, I2 and I3 = Irrigation regime 21,28 and 35 days.

( C ) FACTOR,V1,V2 andV3 = wheat cultivars I.e., Shandaweel-1, GIza-168 and SIds-12

LSD at 0.5 level for:

$\begin{array}{rlll}\mathbf{A} & 0.04 & 0.45 & 0.42 \\ \mathbf{B} & 0.35 & 0.18 & 0.29 \\ \mathbf{A B} & 0.40 & 0.34 & 0.31 \\ \mathbf{C} & 0.45 & 0.22 & 0.37 \\ \mathbf{A C} & 0.50 & 0.43 & 0.40 \\ \mathbf{B C} & 0.61 & 0.53 & 0.49 \\ \mathbf{A B C} & 0.87 & 0.75 & 0.69\end{array}$


Table -5-b. Effect of different sowing dates and irrigation regimes on seeds index (g/1000 grain) of some wheat varieties under Sohag governorate conditions.

\begin{tabular}{|c|c|c|c|c|c|c|c|c|c|c|c|c|c|}
\hline \multirow{4}{*}{$\begin{array}{c}\text { Sowing } \\
\text { date } \\
\text { (A) }\end{array}$} & \multirow{4}{*}{$\begin{array}{l}\text { Irrigatio } \\
\text { regime } \\
\text { (B) }\end{array}$} & \multicolumn{12}{|c|}{ Seed index } \\
\hline & & \multicolumn{4}{|c|}{ 2012/13 season } & \multicolumn{4}{|c|}{ 2013/14 season } & \multicolumn{4}{|c|}{ 2014/15 season } \\
\hline & & \multicolumn{3}{|c|}{ Varieties (C) } & \multirow{2}{*}{ Mean } & \multicolumn{3}{|c|}{ Varieties (C) } & \multirow{2}{*}{ Mean } & \multicolumn{3}{|c|}{ Varieties (C) } & \multirow{2}{*}{ Mean } \\
\hline & & V1 & V2 & V3 & & V1 & V2 & V3 & & V1 & V2 & V3 & \\
\hline \multirow{3}{*}{ S1 } & I1 & 46.620 & 45.167 & 44.413 & 45.400 & 43.340 & 43.147 & 42.303 & 42.930 & 46.207 & 45.570 & 43.923 & 45.233 \\
\hline & I2 & 43.710 & 41.753 & 42.903 & 42.789 & 41.617 & 40.897 & 41.097 & \begin{tabular}{|l|}
41.203 \\
\end{tabular} & 42.293 & 41.213 & 41.313 & 41.607 \\
\hline & I & 41.110 & 39.643 & 35.210 & 38.654 & 40.523 & 38.600 & 37.940 & 39.021 & 41.150 & 39.657 & 37.057 & 39.288 \\
\hline \multicolumn{2}{|c|}{ Mean } & 43.813 & 42.188 & 40.842 & 42.281 & 41.827 & 40.881 & 40.447 & 41.051 & 43.217 & 42.147 & 40.764 & 42.043 \\
\hline \multirow{3}{*}{ S2 } & I1 & 48.340 & 44.700 & 47.510 & 46.850 & 44.387 & 42.800 & 44.337 & 43.841 & 47.317 & 44.073 & 46.840 & 46.077 \\
\hline & I2 & 44.133 & 42.033 & 43.000 & 43.056 & 41.840 & 40.910 & 41.200 & 41.317 & 42.900 & 41.253 & 41.767 & 41.973 \\
\hline & I & 40.733 & 40.113 & 37.210 & 39.352 & 39.927 & 38.883 & 38.333 & 39.048 & 40.767 & 39.950 & 38.760 & 39.826 \\
\hline \multicolumn{2}{|c|}{ Mean } & 44.402 & 42.282 & 42.573 & 43.086 & 42.051 & 40.864 & 41.290 & 41.402 & 43.661 & 41.759 & 42.456 & 42.625 \\
\hline \multirow{3}{*}{$B * C$} & I1 & 47.480 & 44.933 & 45.962 & 46.125 & 43.863 & 42.973 & 43.320 & 43.386 & 46.762 & 44.822 & 45.382 & 45.655 \\
\hline & I2 & 43.922 & 41.893 & 42.952 & 42.922 & 41.728 & 40.903 & 41.148 & 41.260 & 42.597 & 41.233 & 41.540 & 41.790 \\
\hline & I & 40.922 & 39.878 & 36.210 & 39.003 & 40.225 & 38.742 & 38.137 & 39.034 & 40.958 & 39.803 & 37.908 & 39.557 \\
\hline \multicolumn{2}{|c|}{$\operatorname{Mean}(C)$} & 44.108 & 42.235 & 41.708 & & 41.939 & 40.873 & 40.868 & & 43.439 & 41.953 & 41.610 & \\
\hline
\end{tabular}

Where: (A) FACTOR s1, and S2 =Sowing on $20^{\text {th }}$ November, and $5^{\text {th }}$ December. (B)FACTOR I1, I2 and I3 =Irrigation regime 21,28 and 35 days.

( C ) FACTOR,V1,V2 andV3 = wheat cultivars I.e., Shandaweel-1, GIza-168 and SIds-12

LSD at 0.5 level for:

$\begin{array}{rrrr}\mathbf{A} & 2.57 \mathrm{~N} . \mathrm{S} & 0.90 \mathrm{~N} . \mathrm{S} & 4.21 \mathrm{~N} . \mathrm{S} \\ \mathbf{B} & 1.42 & 0.70 & 1.21 \\ \mathbf{A B} & 1.07 & 0.57 & 1.91 \\ \mathbf{C} & 1.80 & 0.88 & 1.53 \\ \mathbf{A C} & 1.35 \mathrm{~N} . \mathrm{S} & 0.72 \mathrm{~N} . \mathrm{S} & 1.41 \mathrm{~N} . \mathrm{S} \\ \mathbf{B C} & 1.66 & 0.88 & 2.95 \\ \mathbf{A B C} & 2.35 & 1.25 & 4.18\end{array}$

Table -6-b. effect of different sowing dates and irrigation regimes on total biological yield $(1000 \mathrm{~kg} / \mathrm{fed})$ of some wheat varieties under Sohag governorate conditions.

\begin{tabular}{|c|c|c|c|c|c|c|c|c|c|c|c|c|c|}
\hline \multirow{4}{*}{$\begin{array}{c}\text { Sowing } \\
\text { date } \\
\text { (A) }\end{array}$} & \multirow{4}{*}{$\begin{array}{l}\text { Irrigation } \\
\text { regime } \\
\text { (B) }\end{array}$} & \multicolumn{12}{|c|}{ Total biological yield $(1000 \mathrm{~kg} / \mathrm{fed})$} \\
\hline & & \multicolumn{4}{|c|}{ 2012/13 season } & \multicolumn{4}{|c|}{$2013 / 14$ season } & \multicolumn{4}{|c|}{$2014 / 15$ season } \\
\hline & & \multicolumn{3}{|c|}{ Varieties (C) } & \multirow{2}{*}{ Mean } & \multicolumn{3}{|c|}{ Varieties (C) } & \multirow{2}{*}{ Mean } & \multicolumn{3}{|c|}{ Varieties (C) } & \multirow{2}{*}{ Mean } \\
\hline & & V1 & V2 & V3 & & V1 & V2 & V3 & & V1 & V2 & V3 & \\
\hline \multirow{3}{*}{ S1 } & I1 & 7.615 & 6.430 & 7.129 & 7.058 & 6.426 & 5.521 & 6.156 & 6.034 & 6.669 & 6.442 & 6.269 & 6.460 \\
\hline & I2 & 6.195 & 6.116 & 5.834 & 6.048 & 5.915 & 6.030 & 5.809 & 5.918 & 6.490 & 5.782 & 5.250 & 5.841 \\
\hline & I3 & 6.228 & 5.750 & 5.761 & 5.913 & 5.647 & 5.626 & 5.625 & 5.633 & 4.989 & 4.802 & 4.618 & 4.803 \\
\hline \multicolumn{2}{|c|}{ Mean } & 6.679 & 6.099 & 6.241 & 6.340 & 5.996 & 5.726 & 5.863 & 5.862 & 6.049 & 5.675 & 5.379 & 5.701 \\
\hline \multirow{3}{*}{ S2 } & I1 & 8.893 & 8.571 & 8.664 & 8.709 & 6.599 & 6.646 & 6.638 & 6.628 & 6.429 & 6.488 & 5.991 & 6.302 \\
\hline & I2 & 7.486 & 7.580 & 7.818 & 7.628 & 6.203 & 5.575 & 6.035 & 5.938 & 5.682 & 5.868 & 5.744 & 5.765 \\
\hline & I3 & 5.669 & 6.170 & 5.646 & 5.828 & 6.348 & 5.349 & 5.431 & 5.709 & 5.514 & 5.548 & 5.409 & 5.490 \\
\hline \multicolumn{2}{|c|}{ Mean } & 7.349 & 7.441 & 7.376 & 7.389 & 6.384 & 5.857 & 6.035 & 6.092 & 5.875 & 5.968 & 5.715 & 5.852 \\
\hline \multirow{3}{*}{$B * C$} & I1 & 8.254 & 7.501 & 7.897 & 7.884 & 6.512 & 6.083 & 6.397 & 6.331 & 6.549 & 6.465 & 6.130 & 6.381 \\
\hline & I2 & 6.841 & 6.848 & 6.826 & 6.838 & 6.059 & 5.802 & 5.922 & 5.928 & 6.086 & 5.825 & 5.497 & 5.803 \\
\hline & I3 & 5.949 & 5.960 & 5.703 & 5.871 & 5.998 & 5.488 & 5.528 & 5.671 & 5.252 & 5.175 & 5.014 & 5.147 \\
\hline \multicolumn{2}{|c|}{ Mean (C) } & 7.014 & 6.770 & 6.809 & & 6.190 & 5.791 & 5.949 & & 5.962 & 5.822 & 5.547 & \\
\hline
\end{tabular}

Where: (A) FACTOR S1, and S2 $=$ Sowing on $20^{\text {th }}$ November, and $5^{\text {th }}$ December. (B)FACTOR I1, I2andI3 =Irrigation regime 21,28 and35days.

( C ) FACTOR,V1,V2 andV3 = wheat cultivars I.e., Shandaweel-1, GIza-168 and SIds-12.

LSD at 0.5 level for:

$\begin{array}{rlll}\mathbf{A} & 0.09 & 0.01 & 0.09 \\ \mathbf{B} & 0.18 & 0.03 & 0.08 \\ \mathbf{A B} & 0.26 & 0.04 & 0.12 \\ \mathbf{C} & 0.08 & 0.06 & 0.05 \\ \mathbf{A C} & 0.11 & 0.08 & 0.07 \\ \mathbf{B C} & 0.14 & 0.10 & 0.09 \\ \mathbf{A B C} & 0.20 & 0.14 & 0.12\end{array}$


Table-7-b. Effect of different sowing dates and irrigation regimes on grain yield $(\mathrm{kg} / \mathrm{fed})$ of some wheat varieties under Sohag governorate conditions

\begin{tabular}{|c|c|c|c|c|c|c|c|c|c|c|c|c|c|}
\hline \multirow{4}{*}{$\begin{array}{l}\text { Sowing } \\
\text { Date } \\
\text { (A) }\end{array}$} & \multirow{4}{*}{$\begin{array}{l}\text { Irrigation } \\
\text { regime } \\
\text { (B) }\end{array}$} & \multicolumn{12}{|c|}{ Grain yield (kg/fed) } \\
\hline & & \multicolumn{4}{|c|}{ 2012/13 season } & \multicolumn{4}{|c|}{ 2013/14 season } & \multicolumn{4}{|c|}{ 2014/15 season } \\
\hline & & \multicolumn{3}{|c|}{ Varieties (C) } & \multirow{2}{*}{ Mean } & \multicolumn{3}{|c|}{ Varieties (C) } & \multirow{2}{*}{ Mean } & \multicolumn{3}{|c|}{ Varieties (C) } & \multirow{2}{*}{ Mean } \\
\hline & & V1 & V2 & V3 & & V1 & V2 & V3 & & V1 & V2 & V3 & \\
\hline \multirow{3}{*}{ S1 } & I1 & 2432.867 & 2217.867 & 2232.667 & 2294.467 & 2483.600 & 2483.600 & 2060.700 & 2257.433 & 2566.667 & 2397.333 & 2486.667 & 2483.556 \\
\hline & I2 & 1793.333 & 1849.500 & 1799.233 & 1814.022 & 2255.133 & 1897.933 & 2100.833 & 2084.633 & 2326.667 & 2040.000 & 2015.533 & 2127.040 \\
\hline & I3 & 1311.000 & 1567.567 & 1372.233 & 1416.933 & 2265.233 & 2200.967 & 2140.967 & 2202.389 & 1870.000 & 2000.000 & 1688.667 & 1852.800 \\
\hline \multicolumn{2}{|c|}{ Mean } & 1845.733 & 1878.311 & 1801.378 & 1841.807 & 2334.656 & 2108.967 & 2100.833 & 2181.485 & 2254.444 & 2145.778 & 2063.622 & 2154.615 \\
\hline \multirow{3}{*}{ S2 } & I1 & 3290.600 & 3122.967 & 3037.267 & 3150.278 & 2662.433 & 2664.467 & 2642.033 & 2656.311 & 2710.333 & 2753.333 & 2566.667 & 2676.778 \\
\hline & I2 & 2534.033 & 2275.467 & 1608.800 & 2139.433 & 2588.267 & 2438.333 & 2528.767 & 2518.456 & 2172.000 & 2592.000 & 2531.000 & 2431.667 \\
\hline & I3 & 1601.000 & 1579.333 & 1784.567 & 1654.967 & 2477.867 & 2172.200 & 2036.967 & 2229.011 & 2351.000 & 2366.667 & 2230.000 & 2315.889 \\
\hline \multicolumn{2}{|c|}{ Mean } & 2475.211 & 2325.922 & 2143.544 & 2314.893 & 2576.189 & 2425.000 & 2402.589 & 2467.926 & 2411.111 & 2570.667 & 2442.556 & 2474.778 \\
\hline \multirow{3}{*}{$B * C$} & I1 & 2861.733 & 2670.417 & 2634.967 & 2722.372 & 2573.017 & 2446.233 & 2351.367 & 2456.872 & 2638.500 & 2575.333 & 2526.667 & 2580.167 \\
\hline & I2 & 2163.683 & 2062.483 & 1704.017 & 1976.728 & 2421.700 & 2168.133 & 2314.800 & 2301.544 & 2249.333 & 2316.000 & 2273.267 & 2279.533 \\
\hline & I3 & 1456.000 & 1573.450 & 1578.400 & 1535.950 & 2371.550 & 2186.583 & 2088.967 & 2215.700 & 2110.500 & 2183.333 & 1959.333 & 2084.389 \\
\hline \multicolumn{2}{|c|}{ Mean } & 2160.472 & 2102.117 & 1972.461 & & 2455.422 & 2266.983 & 2251.711 & & 2332.778 & 2358.222 & 2253.089 & \\
\hline
\end{tabular}

Where: (A) FACTOR s1, and S2 $=$ Sowing on $20^{\text {th }}$ November, and $5^{\text {th }}$ December. (B)FACTOR I1, I2 andI3 =Irrigation regime 21,28 and35days.

( C ) FACTOR,V1,V2 andV3 = wheat cultivars I.e., Shandaweel-1, GIza-168 and SIds-12

LSD at 0.5 level for:

$\begin{array}{rrcc}\mathbf{A} & 341.14 & 28.16 & 101.64 \\ \mathbf{B} & 258.48 & 19.44 & 111.33 \\ \mathbf{C} & 191.81 & 17.57 & 70.47 \\ \mathbf{A B} & 365.55 & 27.49 & 157.44 \\ \mathbf{A C} & 271.26 & 24.85 & 99.66 \\ \mathbf{B C} & 332.22 & 30.44 & 122.06 \\ \mathbf{A B C} & 469.83 & 43.05 & 172.62\end{array}$

Table -8-b. Effect of different sowing dates and irrigation regimes on straw yield $(100 \mathrm{~kg} / \mathrm{fed})$ of some wheat varieties under Sohag governorate conditions

\begin{tabular}{|c|c|c|c|c|c|c|c|c|c|c|c|c|c|}
\hline \multirow{4}{*}{$\begin{array}{c}\text { Sowing } \\
\text { date } \\
\text { (A) }\end{array}$} & \multirow{4}{*}{$\begin{array}{c}\text { Irrigatio } \\
\text { regime } \\
\text { (B) }\end{array}$} & \multicolumn{12}{|c|}{ Straw yield $(100 \mathrm{~kg} / \mathrm{fed})$} \\
\hline & & \multicolumn{4}{|c|}{ 2012/13 season } & \multicolumn{4}{|c|}{ 2013/14 season } & \multicolumn{4}{|c|}{ 2014/15 season } \\
\hline & & \multicolumn{3}{|c|}{ Varieties (C) } & \multirow{2}{*}{ Mean } & \multicolumn{3}{|c|}{ Varieties $(\mathbf{C})$} & \multirow{2}{*}{ Mean } & \multicolumn{3}{|c|}{ Varieties $(\mathbf{C})$} & \multirow{2}{*}{ Mean } \\
\hline & & V1 & V2 & V3 & & V1 & V2 & V3 & & V1 & V2 & V3 & \\
\hline \multirow[b]{3}{*}{$S$} & I1 & 5.182 & 4.212 & 4.897 & 4.764 & 3.942 & 3.293 & 3.901 & 3.712 & 4.102 & 4.013 & 3.797 & 3.971 \\
\hline & I2 & 4.369 & 4.250 & 4.047 & 22 & 3.660 & 4.125 & 3.708 & 3.831 & 4.129 & 3.709 & 3.234 & 91 \\
\hline & $\mathbf{I 3}$ & 4.917 & 4.182 & 4.372 & 90 & 3.382 & 3.425 & 3.481 & 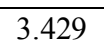 & 3.119 & 2.802 & 2.926 & 2.949 \\
\hline \multicolumn{2}{|c|}{ Mean } & 4.822 & 4.215 & 4.439 & 4.492 & 3.661 & 3.615 & 3.697 & 3.657 & 3.783 & 3.508 & 3.319 & 3.537 \\
\hline \multirow{3}{*}{ S2 } & I1 & 5.525 & 5.448 & 5.627 & 5.533 & 3.937 & 3.981 & 3.983 & 3.967 & 3.732 & 3.728 & 3.438 & 3.632 \\
\hline & I2 & 4.952 & 5.288 & 5.543 & 5.261 & 3.625 & 3.136 & 3.520 & 3.427 & 3.510 & 3.276 & 3.223 & 3.336 \\
\hline & I3 & 4.068 & 4.591 & 3.861 & 4.173 & 3.867 & 3.173 & 3.394 & 3.478 & 3.163 & 3.181 & 3.055 & 3.133 \\
\hline \multicolumn{2}{|c|}{ Mean } & 4.848 & 5.109 & 5.010 & 4.989 & 3.809 & 3.430 & 3.632 & 3.624 & 3.468 & 3.395 & 3.239 & 3.367 \\
\hline \multirow{3}{*}{$B * C$} & I1 & 5.353 & 4.830 & 5.262 & 5.148 & 3.939 & \begin{tabular}{|l|l}
3.637 \\
\end{tabular} & 3.942 & 3.839 & 3.917 & 3.870 & 3.618 & 3.802 \\
\hline & 12 & 4.660 & 4.769 & 4.795 & 4.741 & 3.642 & 3.631 & 3.614 & 3.629 & 3.819 & 3.492 & 3.229 & 3.514 \\
\hline & I3 & 4.493 & 4.386 & 4.117 & 4.332 & 3.624 & 3.299 & 3.437 & 3.454 & 3.141 & 2.991 & 2.991 & 3.041 \\
\hline \multicolumn{2}{|c|}{$\operatorname{Mean}(C)$} & 4.835 & 4.662 & 4.724 & & 3.735 & 3.522 & 3.664 & & 3.626 & 3.451 & 3.279 & 3.452 \\
\hline
\end{tabular}

Where: (A) FACTOR s1, and S2 =Sowing on 20th November, and 5th December. (B)FACTOR I1, I2 andI3 =Irrigation regime 21, 28 and35days. (C) FACTOR,V1,V2 andV3 = wheat cultivars I.e., Shandaweel-1, GIza-168 and SIds-12

LSD at 0.5 level for:

$\begin{array}{rlll}\mathbf{A} & 0.07 & 0.02 & 0.06 \\ \mathbf{B} & 0.15 & 0.03 & 0.04 \\ \mathbf{A B} & 0.21 & 0.04 & 0.06 \\ \mathbf{C} & 0.07 & 0.04 & 0.03 \\ \mathbf{A C} & 0.10 & 0.06 & 0.04 \\ \mathbf{B C} & 0.12 & 0.08 & 0.05 \\ \mathbf{A B C} & 0.17 & 0.11 & 0.07\end{array}$


Table-9-b. Seasonal water consumptive use $\left(\mathrm{m}^{3} / \mathrm{fed}\right)$ of wheat cultivars i.e., Shandaweel-1, Giza-168 and Sids-12 as affected by water regime and sowing date at Shandaweel region in the three seasons $(2012 / 2013,2013 / 2014$ and 2014/2015).

\begin{tabular}{|c|c|c|c|c|c|c|c|c|c|c|c|c|c|}
\hline \multirow{3}{*}{$\begin{array}{l}\text { Sowing } \\
\text { Date } \\
\text { (A) }\end{array}$} & \multirow{3}{*}{$\begin{array}{l}\text { Irrigation regime } \\
\text { (B) }\end{array}$} & \multicolumn{12}{|c|}{ Water consumptive use $\left(\mathrm{m}^{3} /\right.$ fed $)$} \\
\hline & & \multicolumn{3}{|c|}{ 2012/2013 } & \multirow{2}{*}{ MEAN } & \multicolumn{3}{|c|}{$2013 / 2014$} & \multirow{2}{*}{ MEAN } & \multicolumn{3}{|c|}{$2014 / 2015$} & \multirow{2}{*}{ MEAN } \\
\hline & & V1 & G168 & V3 & & V1 & G168 & V3 & & V1 & G168 & V3 & \\
\hline \multirow{3}{*}{ S1 } & I1 & 2134 & 2445 & 2026 & 2202 & 2156 & 2053 & 1990 & 2066 & 2026 & 2124 & 1896 & 2015 \\
\hline & $\mathrm{I} 2$ & 1984 & 1917 & 1868 & 1923 & 1911 & 1931 & 1903 & 1915 & 1839 & 1817 & 1781 & 1812 \\
\hline & $\mathrm{I} 3$ & 1647 & 1561 & 1589 & 1599 & 1672 & 1579 & 1514 & 1588 & 1567 & 1483 & 1465 & 1505 \\
\hline \multicolumn{2}{|r|}{ MEAN } & 1922 & 1974 & 1844 & 1908 & 1913 & 1854 & 1802 & 1857 & 1811 & 1807 & 1714 & 1778 \\
\hline \multirow{3}{*}{ S2 } & I1 & 2202 & 2218 & 2139 & 2186 & 2145 & 2145 & 2135 & 2142 & 2053 & 2060 & 2018 & 2044 \\
\hline & $\mathrm{I} 2$ & 1730 & 1933 & 1813 & 1825 & 1723 & 1995 & 1880 & 1866 & 1631 & 1855 & 1744 & 1743 \\
\hline & $\mathrm{I} 3$ & 1567 & 1734 & 1627 & 1643 & 1535 & 1744 & 1612 & 1630 & 1465 & 1642 & 1530 & 1546 \\
\hline \multicolumn{2}{|r|}{ MEAN } & 1833 & 1962 & 1860 & 1885 & 1801 & 1961 & 1876 & 1879 & 1716 & 1853 & 1764 & 1777 \\
\hline \multirow{3}{*}{$\left(B^{*} \mathrm{C}\right)$} & I1 & 2168 & 2332 & 2083 & 2194 & 2151 & 2099 & 2063 & 2104 & 2039 & 2092 & 1957 & 2030 \\
\hline & $\mathrm{I} 2$ & 1857 & 1925 & 1841 & 1874 & 1817 & 1963 & 1892 & 1890 & 1735 & 1836 & 1762 & 1778 \\
\hline & $\mathrm{I} 3$ & 1607 & 1648 & 1608 & 1620 & 1604 & 1662 & 1563 & 1609 & 1516 & 1563 & 1497 & 1525 \\
\hline \multicolumn{2}{|r|}{$\operatorname{MEAN}(\mathrm{C})$} & 1877 & 1968 & 1844 & 1896 & 1857 & 1908 & 1839 & 1867 & 1763 & 1830 & 1739 & 1777 \\
\hline
\end{tabular}

Where: (A) FACTOR s1, and S2 $=$ sowing on $20^{\text {th }}$ November, and $5^{\text {th }}$ December. (B)FACTOR I1,I2andI3 =Irrigation regime 21,28 and35days.

( C ) FACTOR,V1,V2 andV3 = wheat cultivars i.e., Shandaweel-1, Giza-168 and Sids-12

Table -10-b. Seasonal Water use efficiency (WUE)of wheat cultivars i.e., Shandaweel-1, Giza-168 and Sids-12 as affected by water regime and sowing date at Shandaweel region in the three seasons $(2012 / 2013,2013 / 2014$ and 2014/2015).

\begin{tabular}{|c|c|c|c|c|c|c|c|c|c|c|c|c|c|}
\hline \multirow{3}{*}{$\begin{array}{l}\text { Sowing } \\
\text { Date(A) }\end{array}$} & \multirow{3}{*}{$\begin{array}{l}\text { Irrigation } \\
\text { regime } \\
\text { (B) }\end{array}$} & \multicolumn{12}{|c|}{ WUE (kg grain/m $\mathbf{m}^{3}$ ) } \\
\hline & & \multicolumn{3}{|c|}{$2012 / 2013$} & \multirow{2}{*}{ MEAN } & \multicolumn{3}{|c|}{$2013 / 2014$} & \multirow{2}{*}{ MEAN } & \multicolumn{3}{|c|}{$2014 / 2015$} & \multirow{2}{*}{ MEAN } \\
\hline & & V1 & V2 & V3 & & V1 & $\mathrm{V} 2$ & $\mathrm{~V} 3$ & & V1 & V2 & V3 & \\
\hline \multirow{3}{*}{ S1 } & I1 & 1.140 & 0.907 & 1.102 & 1.050 & 1.152 & 1.085 & 1.133 & 1.123 & 1.267 & 1.144 & 1.303 & 1.238 \\
\hline & $\mathrm{I} 2$ & 0.921 & 0.973 & 0.956 & 0.950 & 1.180 & 0.986 & 1.104 & 1.090 & 1.284 & 1.141 & 1.132 & 1.186 \\
\hline & $\mathrm{I} 3$ & 0.796 & 1.004 & 0.874 & 0.891 & 1.355 & 1.394 & 1.416 & 1.388 & 1.193 & 1.349 & 1.155 & .232 \\
\hline \multicolumn{2}{|c|}{ Mean } & 0.952 & 0.962 & 0.977 & 0.964 & 1.229 & 1.155 & 1.218 & 1.201 & 1.248 & 1.211 & 1.197 & 1.219 \\
\hline \multirow{3}{*}{ S2 } & I1 & 1.529 & 1.408 & 1.420 & 1.452 & 1.241 & 1.242 & 1.244 & 1.242 & 1.314 & 1.340 & 1.265 & 1.306 \\
\hline & $\mathrm{I} 2$ & 1.465 & 1.186 & 1.255 & 1.302 & 1.496 & 1.222 & 1.338 & 1.352 & 1.332 & 1.397 & 1.446 & 1.392 \\
\hline & $\mathrm{I3}$ & 1.022 & 0.911 & 1.097 & 1.010 & 1.616 & 1.247 & 1.264 & 1.376 & 1.605 & 1.441 & 1.539 & 1.528 \\
\hline \multicolumn{2}{|c|}{ Mean } & 1.339 & 1.168 & 1.257 & 1.255 & 1.451 & 1.237 & 1.282 & 1.323 & 1.417 & 1.393 & 1.416 & 1.409 \\
\hline \multirow{3}{*}{$B * C$} & I1 & 1.335 & 1.158 & 1.261 & 1.251 & 1.197 & 1.164 & 1.188 & 1.183 & 1.290 & 1.242 & 1.284 & 1.272 \\
\hline & $\mathrm{I} 2$ & 1.193 & 1.080 & 1.106 & 1.126 & 1.338 & 1.104 & 1.221 & 1.221 & 1.308 & 1.269 & 1.289 & 1.289 \\
\hline & $\mathrm{I} 3$ & .909 & 0.958 & 0.985 & 0.951 & 1.486 & 1.321 & 1.340 & 1.382 & 1.399 & 1.395 & 1.347 & 1.380 \\
\hline \multicolumn{2}{|c|}{ Mean( C) } & 1.145 & 1.065 & 1.117 & & 1.340 & 1.196 & 1.250 & & 1.332 & 1.302 & 1.307 & \\
\hline
\end{tabular}

Where: (A) FACTOR s1, and S2 $=$ sowing on $20^{\text {th }}$ November, and $5^{\text {th }}$ December. (B)FACTOR I1,I2 and I3 =Irrigation regime 21,28 and35days.(C) FACTOR,V1,V2 andV3 = wheat cultivars i.e., Shandaweel-1, Giza-168 and Sids-12.

\section{References}

Bermner, J.M. and C.S. Mulvaney. 1982."Total nitrogen" Amer. Soc. of Agron., Madison, Wisconsin, USA 595-624.

Blake, G.R., and K.H. Hartge. 1986a. Bulk Density. In A. Klute (ed.) Methods of Soil Analysis. Part 1 Physical and Mineralogical Methods Second Edition. American Society of Agronomy, Madison WI.
Cassel, D.K., and D.R. Nielsen.1986. Field Capacity and Available Water Capacity. In Page, A.L., R.H. Miller and D.R. Keeney (eds.) Methods of Soil Analysis Part 2: Chemical and Microbiological Properties. Second Edition. Agronomy Society of America, Madison, WI.

Eid, H.M., N.G. Ainer, S.M. ElMarsafawy and A.N.Khater. 1999. Crop water needs under different ir- 
rigation systems in the new lands. Third Conf. of On-Farm Irrigation and Agrocilmatology. Soil, Water and Env. Res. Inst., ARC. Ministry of Agric. and Land Reclamation. Jauary 25-27.

El- Sabbagh, A.A., S.A. Abd El- Hafez, A.Z. El-Babbly and E.I. AbouAhmed.2002. Response of wheat crop to irrigation intervals and foliar application of potassium. J. agric. Res. Tanta Univ., 28(2):525-538.

El-Kalla, S.E.A.E., A.A.Leilah, A.H. Basiony and S.M. Hussein.1994. Effect of irrigation and foliar nutrition treatments on growth and yield of some wheat cultivars under Al-Arish area conditions. Proc.6th Conf. Agron., Al-Azhar Univ., Cairo, 1:362-378.

El-Marsafawy, S.M. 2000. Scheduling irrigation of wheat crop under different phosphorus fertilizer application times in Middle Egypt. Proc. $5^{\text {th }}$ Conference - Meteorology \& Sustainable Development: 182-195.

El-Shear, M.H., C. Rosen Zweig, A. Iglesias H. M. Eid and D. Hellil.1997. Impact of climate change on possible scenarios for Egyptian agriculture in the future. Mitigation and Adaptation Strategies for Global Change. 1: 233-250.

FAO.2008. Statistical databases, Food composition table for use in the Near East. http//www.fao.org.com.

Gee, G.W., and J.W. Bauder.1986. Particle Size Analysis. In Page, A.L., R.H. Miller and D.R. Keeney (eds.) Methods of Soil Analysis Part 2: Chemical and Microbiological Properties. Second Edition. Agronomy Society of America, Madison, WI.

Hesse, P.R.1972.A textbook of soil chemical analysis. Chem. Pub. Co. Inc, New York.

Israelson, O. W. and V. E. Hansen. 1962. Flow water into and through soils. Irrigation principles and practices. 3th Edition, John Wiley and Sons, Ine., New York, N. Y., U.S.A.

Kater, A. N.; Abdel Maksod and H. M. Eid. 1997. Response of some wheat cultivars and their water relations to different irrigation levels in Middle delta. Egypt, J.Appl. Sci.

Khalil, F.A.F., G.A. El-Saharawi and H.Y.M. Hasan. 2005. Irrigation scheduling for some wheat cultivars through pan evaporation norms and its effect on growth, yield and water use efficiency Fayoum J. Agric. Res \& dev., 21 (1):1-15.

Khalil, F.A.F.; Tammam, A.M. Amin, I.M. and Mohamed, K.A.2006. Scheduling irrigation for some wheat cultivars under Upper Egypt condition. J. Agric. Sci. Mansoura Univ., 31(1):561-572.

McLean, E.O. 1982. Soil pH and lime requirement. In Page, A.L., R.H. Miller and D.R. Keeney (eds.) Methods of soil analysis part 2: Chemical and Microbiological Properties. Second Edition. Agronomy Society of America, Madison, WI.

Metin-Sezen and Attila-Yazar. 2006. Wheat yield response to -source sprinkler irrigation in the arid Southeast Anatolia region of Turkey. Agri. Water Management, 81 (1-2): 59-76.

Mohamed. K.A; and A.M. Tammam.1999. Drought resistance of some wheat varieties in Upper Egypt. Third Conf .On - Farm Irri \& Agroclimtology SWERI, A R C Egypt . 1 (2): 623632.

Moussa, A.M. and Abdel-maksoud H.H. (2004). Effect of soil moisture regime on yield and its components and water use efficiency for some wheat cultivars. Annalas Agric. Sci., Ain Shams Univ., Cairo, 49 (2):515530.

Olsen, S.R, O.V. Cole, F.S. Watanabe and A.L. Dean. 1954. Estimation of available Phosphorus in soil by ex- 
traction with Sodium bicarbonate. U.S.D.A. Circ., 939.

Rayan, A.A.; S.M. El-Marsafawy and K.A.Mohamed.1999. Response of wheat varieties to different sowing dates and irrigation regimes in Upper Egypt. $3{ }^{\text {rd }}$ Conf. on Farm Irrigation and Agro climatology, Giza, Paper No. 44.

Rayan, A. A., S. M. El-Marsafawy, N.G. Ainer and S.E. Soliman. 2000. Schedule irrigation of wheat crop in Upper Egypt under some sowing dates. Egypt. J. Appl. Sci., 15(1): 10-23.

Richards, L. A. (US Salinity Laboratory) 1954. Diagnosis and Improvement of Saline and Alkaline Soil (M). US
Department of Agriculture Hand Book, p:60.

Sidrak, N.N. 2003. Scheduling irrigation of wheat using the evaporation pan method under different times and rates of nitrogen fertilizer. "M.Sc. Thesis, Fac.of Agric. Zagazig Univ. Egypt.

Steel, R.G.D. and Torrie, J.H. 1982. Principals and Procedures of Statistics A Biometrical Approach. Mc Graw Hill Book Company, New York. USA.

Vites, F.G.Jr 1965. Increasing water use efficiency by soil management. Amer. Soc. Agron., Madison, Wisc. P.259. 
تاثير مواعيد الزراعه و فترات الرى المختلفه على النمو والمحصول والاستهلاك المائى لبعض

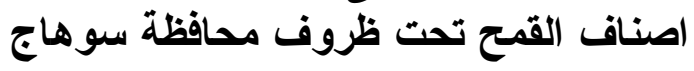

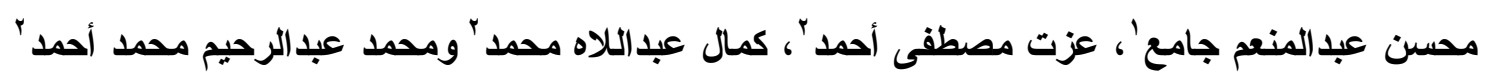

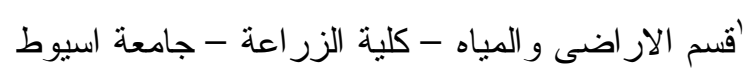
rمعة بحوث الار اضى و المياه و البيئة- مركز البحوث الزر اعية - الجيزه الزئة

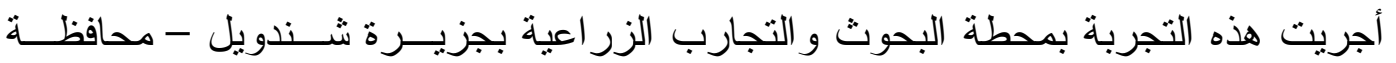

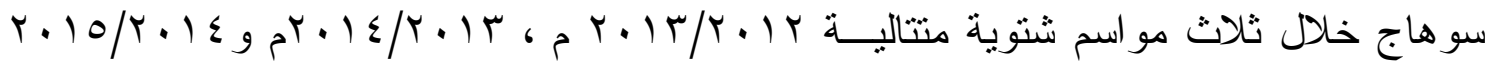

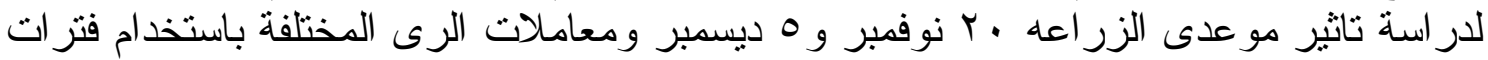

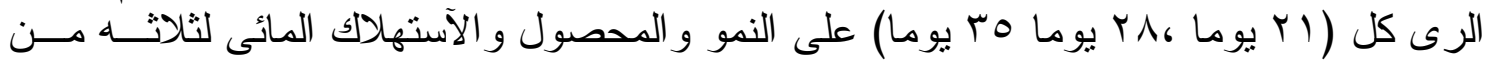

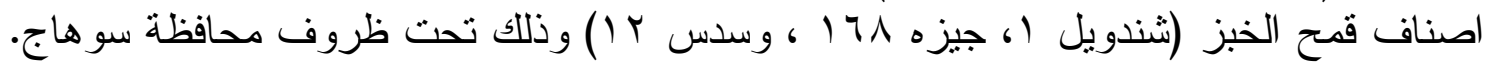

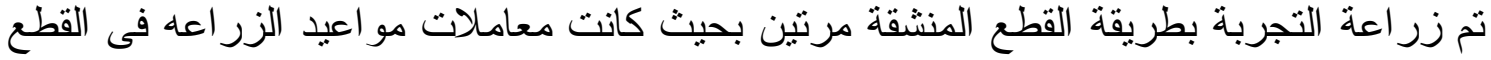

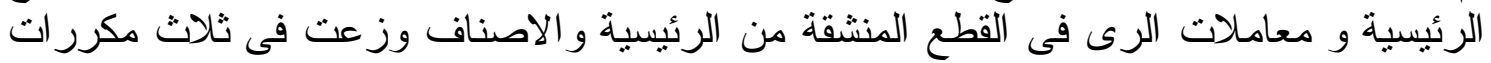
على القطع المنشقة مرنين.

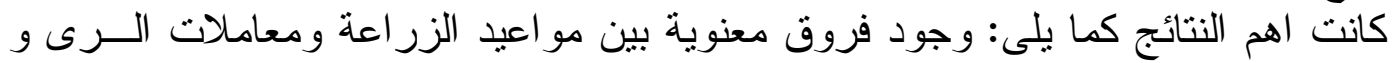

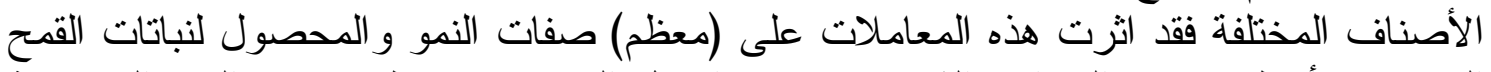

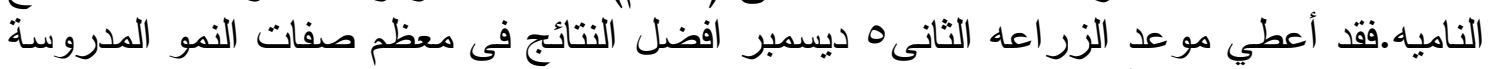

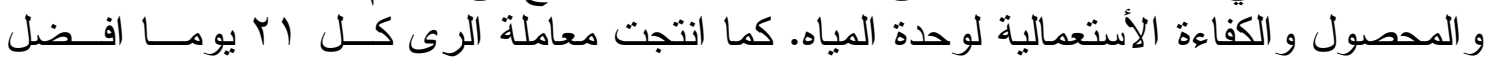

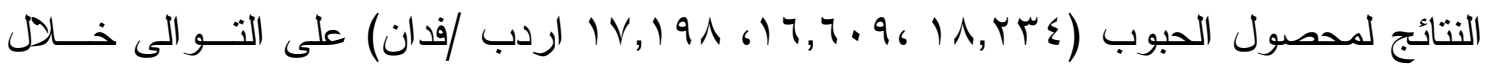

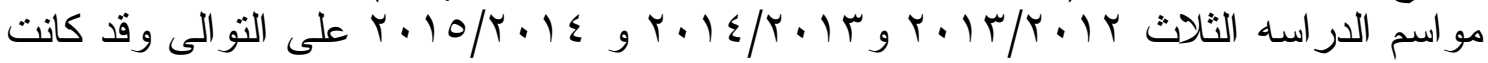

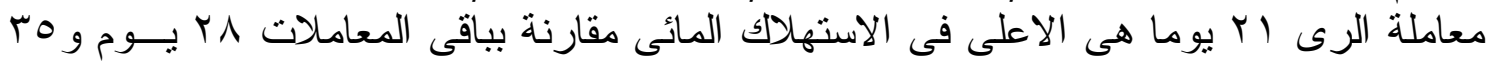

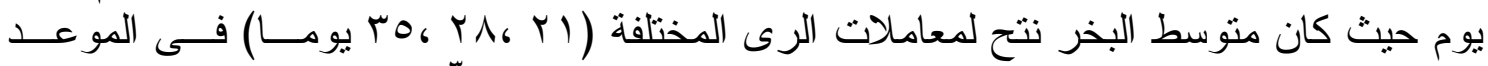

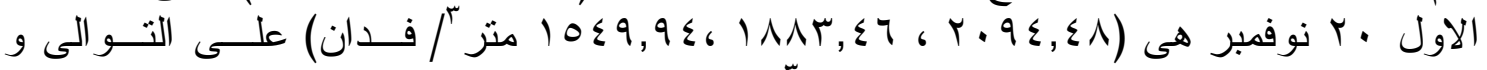

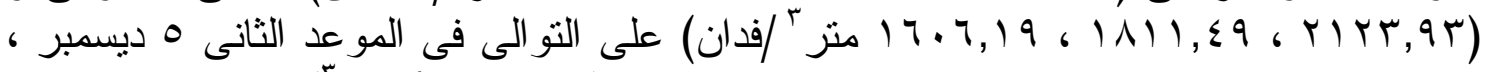

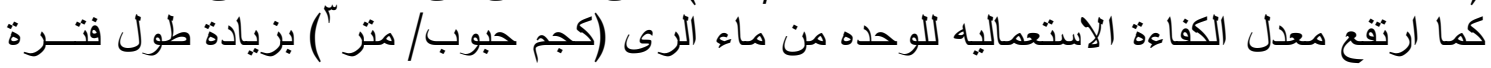

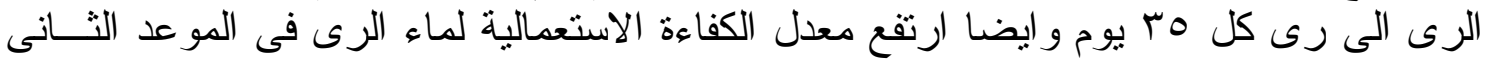

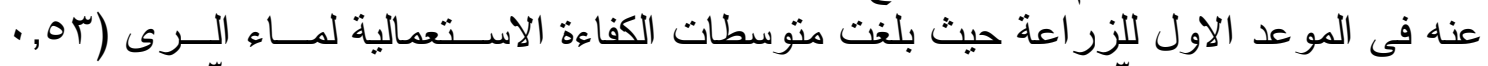

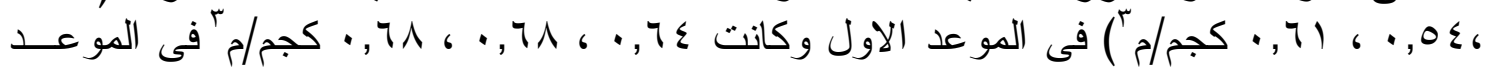

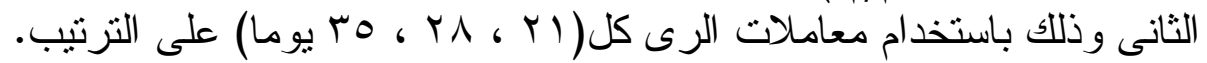

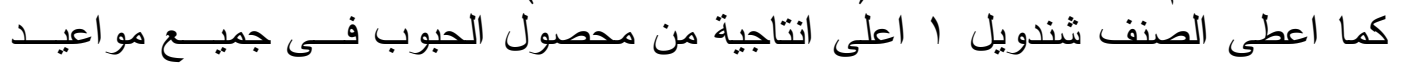

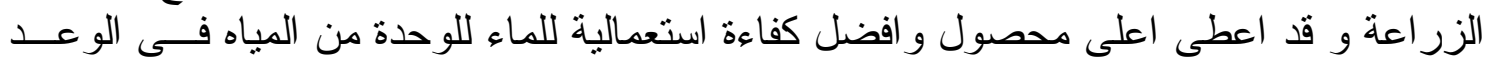
الثانى. 